\title{
Susceptibility of the In-shell Brazil Nut Mycoflora and Aflatoxin Contamination to Ozone Gas Treatment during Storage
}

\author{
Barbara Nantua Evangelista Giordano ${ }^{1}$, Janaina Nones $^{1} \&$ Vildes Maria Scussel ${ }^{1}$ \\ ${ }^{1}$ Food Science and Technology Department, Center of Agricultural Sciences, Federal University of Santa \\ Catarina, Brazil
}

Correspondence: Vildes Maria Scussel, Food Science and Technology Department, Center of Agricultural Sciences, Federal University of Santa Catarina, UFSC, PO Box 476, Florianopolis, SC, CEP 88034-001, Brazil. Tel: 55-48-3721-5386. E-mail: vildescussel_2000@yahoo.co.uk

Received: January 30, 2012 Accepted: February 20, 2012 Online Published: June 29, 2012

doi:10.5539/jas.v4n8p1 URL: http://dx.doi.org/10.5539/jas.v4n8p1

\begin{abstract}
The effect on fungi load, toxigenic Aspergillus strains and aflatoxin (AFL) contamination of stored in-shell Brazil nut (Bertholletia excelsa H.B.K.) ozone $\left(\mathrm{O}_{3}\right)$ gas treated were evaluated. Groups of nuts obtained from retail market were submitted to $\mathrm{O}_{3}$ atmosphere at different concentrations $(10,14,31.5 \mathrm{mg} / \mathrm{l})$ and stored for 180 days. The $\mathrm{O}_{3}$ treatment affected Brazil nuts mycoflora growth, reduced their moisture content (mc) and degraded AFLs. From the three $\mathrm{O}_{3}$ concentrations applied, $31 \mathrm{mg} / 1$ ( 5 hours exposition) was able to successfully destroy fungi contamination (initial: $4.83 \mathrm{logcfu} / \mathrm{g}$ to ng-no grow), including the Aspergillus flavus and A. parasiticus species, since Day One after application. On the other hand, they were still able to grow, at the lower $\mathrm{O}_{3}$ concentrations $(10$; $14 \mathrm{mg} / \mathrm{l}$ ), however only in the first days of storage and at reduced number though (from 4.83 to $3.5 / 3.3 \mathrm{logcfu} / \mathrm{g}$, respectively). Despite of the $\mathrm{O}_{3}$ concentrations applied, AFLs were not detected in all nut samples $\mathrm{O}_{3}$ treated since Day One of application up to the method LOQ of $1.34 \mu \mathrm{g} / \mathrm{kg}$ except for $10 \mathrm{mg} / \mathrm{kg}$ ). As expected, a reduction of mc (9.43 to $7.32 \%)$ and $\mathrm{a}_{\mathrm{w}}(0.82$ to 0.63$)$ due to gas stream application was registered throughout the storage period, which increased with the $\mathrm{O}_{3}$ time of exposure resulting cruncher Brazil nuts. Apart from low cost and simple technology to be applied during storage in-land or in containers before shipping, $\mathrm{O}_{3}$ treatment it is a promising alternative for contamination control and is environment friendly.
\end{abstract}

Keywords: in-shell Brazil nut, ozone, mycoflora, aflatoxin, storage

\section{Introduction}

Brazil nut (Bertholletia excelsa H.B.K.) grows in the Amazon rainforest and is widely recognized as the cornerstone species of the Amazonian extractive economy (Pacheco \& Scussel, 2006). Aflatoxins (AFLs) contamination produced by aflatoxigenic fungi strains of Aspergillus species, such as A. flavus (Freire et al., 2000; Pacheco \& Scussel, 2009) and A. nomius (Kurtzman et al., 1987, Olsen et al., 2008), can be a potential problem for Brazil nuts (CAC, 2005).

As most of the nuts, fungi can grow both, on the shell and inside the nuts when shells are cracked or through the opercula and, if the strains are toxigenic, can produce AFLs (Freire et al., 2000; De-Mello \& Scussel, 2007).

Several environmental factors are known to influence fungi growth and AFL production, being temperature, relative humidity $(\mathrm{RH})$ and moisture content $(\mathrm{mc})$ the most critical. Studies performed on hazelnuts and pistachios suggested that optimum temperature and RH for AFLs production are 25 to $30{ }^{\circ} \mathrm{C}$ and 97 to $99 \%$, respectively (Simsek et al., 2002). In a study carried out in Brazil nuts by Arrus et al. (2005), the authors reported optimal conditions for $A$. flavus growth: mc of $8.6 \%$, water activity $\left(\mathrm{a}_{\mathrm{w}}\right)$ of 0.91 , at $97 \% \mathrm{RH}$ and $30^{\circ} \mathrm{C}$. The Codex Alimentarium Commission (CAC) consider me below the maximum limit accepted for international trade of $13 \pm 2 \%$ and $\mathrm{a}_{\mathrm{w}}<0.70$ as safe for toxigenic fungi growth (CAC, 2006).

To prevent, destroy and/or control fungi proliferation and reduce AFL contamination, several physical and chemical methods, such as microwave heating or treatments with ammonia or ozone $\left(\mathrm{O}_{3}\right)$ have been reported (Dollear et al., 1968; Farag et al., 2006).

Ozonation, an oxidation method by the triatomic oxygen $\left(\mathrm{O}_{3}\right)$, has been reported to be a quite powerful disinfectant and oxidizing agent (McKenzie et al., 1997). One of the important usages of $\mathrm{O}_{3}$ in agriculture is the post-harvest treatment of crops. It can be applied to food as a gas or dissolved in water. The main purposes of $\mathrm{O}_{3}$ application at the post-harvest stage are as follows: inactivation of bacterial growth (Sharma et al., 2002), 
prevention of fungal decay (Perez et al., 1999; Olmez et al., 2009) destruction of pesticides and chemical residues (Hwang et al., 2001) and control of storage pests (Kells et al., 2001). The attractive aspect of $\mathrm{O}_{3}$ is that it decomposes rapidly (half-life of 20-50 min) to molecular oxygen without leaving a residue (Kells et al., 2001).

Aiming reduction of fungi and bacteria growth, several studies on $\mathrm{O}_{3}$ application have been developed in dried figs (Oztekin et al., 2006), barley (Allen et al., 2003), pistachio (Yesilcimen et al., 2006) among other foods. Oztekin et al. (2006) reported reduction of microorganism counts on dried figs at a minimum of 3 hours treatment at $5 \mathrm{mg} / \mathrm{l}$ of $\mathrm{O}_{3}$, decreasing the total yeast/fungi counts of $72 \%$. In post-harvest of strawberry, Perez et al. (1999) observed fungal decay after 4 days of storage under ozonation. Lanita \& da Silva (2008) utilized $\mathrm{O}_{3}$ for controlling fungi in Parmesan cheese maturation (total fungi count reduced from 10 to $3.7 \mathrm{cfu} / \mathrm{plate}$ ). In barley, treated with $\mathrm{O}_{3}$ at $0.16 \mathrm{mg} / 1,96 \%$ of fungi spores of inactivation observed was (Allen et al., 2003). Five $\mathrm{mg} / \mathrm{l}$ of $\mathrm{O}_{3}$ inhibited the surface growth, sporulation and mycotoxin production of cultures of Aspergillus flavus Link and Fusarium verticilioides (Mason et al., 1997). Regarding the effect on AFLs detoxification, $\mathrm{O}_{3}$ reacts across the 8,9 double bond of that toxin furan ring through electrophilic attack, forming primary ozonides. By rearrangement, they are transformed into monozonide derivatives (aldehydes, ketones and organic acids) (Proctor et al., 2004). That reaction results in decrease of AFL concentration over time (McKenzie et al., 1997). Yesilcimen and Murat (2006) studied pistachio exposure to $\mathrm{O}_{3}(5.0,7.0$ and $9.0 \mathrm{mg} / \mathrm{l})$ and found that $\mathrm{AFB}_{1}$ and total AFLs were highly reduced. $\mathrm{O}_{3}$ also was effective to reduce or eliminate AFL from cottonseed and peanut meal (Dollear et al., 1968).

Considering that fungi deterioration is found mostly on the in-shell Brazil nut shell cracked parts and in the microclimate between the shell and the brown peel; fungi can grow during storage \& shipping under favorable $\left(\mathrm{RH}\right.$ and $\mathrm{T}^{\circ} \mathrm{C}$ ) conditions being able to produce toxins; $\mathrm{O}_{3}$ has been utilized in different food commodities for fungi destruction; and some studies reported its effect on AFLs degradation; a work was carried out to study the influence of in-shell Brazil nut $\mathrm{O}_{3}$ treatment on mycoflora and AFL levels at different time of exposure during storage.

\section{Materials and Methods}

\subsection{Sample}

Dry (processed) in-shell Brazil nuts (14 kg), Medium size Type (40-50 mm length) (De-Mello and Scussel., 2007). Naturally AFL contaminated batch obtained in the retail market was chosen for the study. Its initial AFLs $\left(\mathrm{AFB}_{1}+\mathrm{AFB}_{2}+\mathrm{AFG}_{1}+\mathrm{AFG}_{2}\right.$ ) leveltotal fungi count, $\mathrm{mc}$ and $\mathrm{a}_{w}$ of $4.83 \log \mathrm{cfu} / \mathrm{g}, 9.43 \%$ and 0.82 , respectively.

\subsection{Reagents, Solvents, Standards and Culture Media}

Reagents. Potassium iodine; sulphuric acid; sodium thiosulfate and sodium hypochlorite (Vetec, Rio de Janeiro, Brazil). All Analar grade. Solvents. Methanol; acetonitrile and toluene (Carlo Erba, Milano, Italy). All HPLC grade. Ultrapure water (MilliQ system - Millipore, Sao Paulo, Brazil), starch indicator (Synth, Sao Paulo, Brazil) and tween 80 (CRQ, Sao Paulo, Brazil). Aflatoxin Standards: $\mathrm{AFB}_{1}, \mathrm{AFB}_{2}, \mathrm{AFG}_{1}$ and $\mathrm{AFG}_{2}$, crystals, $1 \mathrm{mg}$ (Sigma, Steinheim, Germany). Culture media: malt extract agar-MEA; peptone agar (Himedia, Mumbai, India); Aspergillus flavus and parasiticus agar-AFPA (Fluka, Steinheim, Germany).

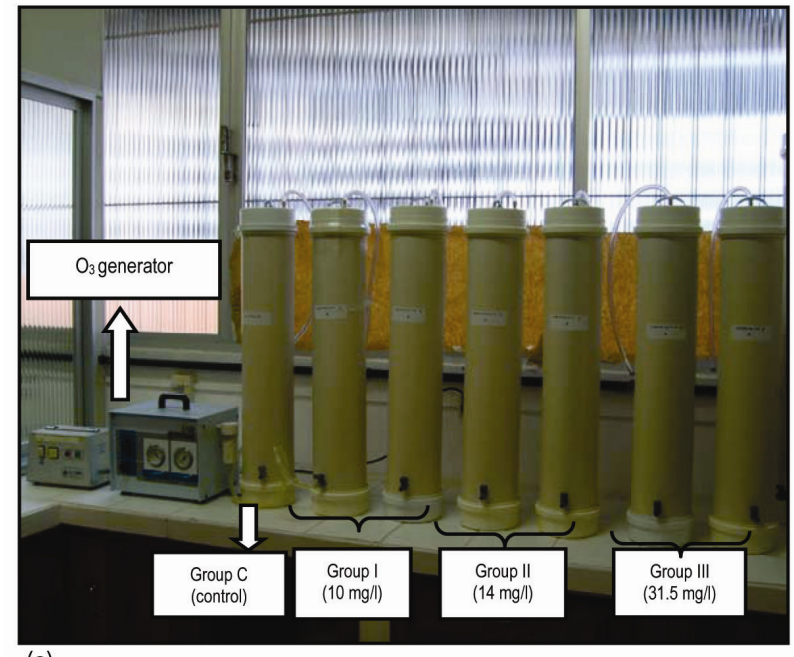

(a)

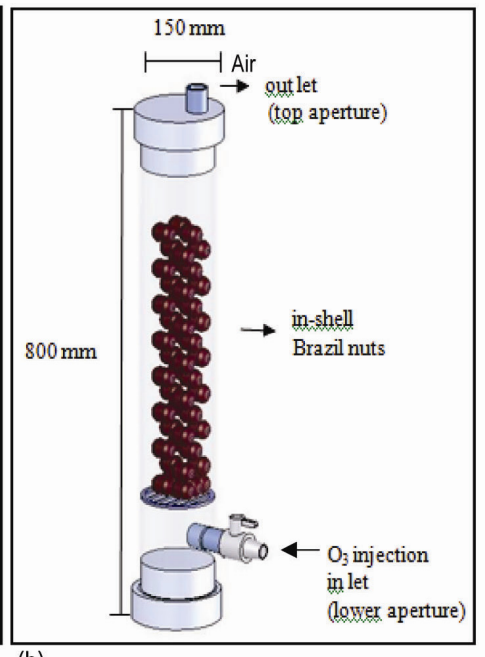

(b)

Figure 1. Brazil nut ozone treatment and storage system: (a) silos ( $\mathrm{n}=7$ ) and $\mathrm{O}_{3}$ generator; (b) silo details and dimensions 


\subsection{Equipment and Apparatus}

Seven vertical silos ( $2 \mathrm{~kg}$ capacity each) made of vinyl polychloride ( $800 \times 150 \times 2 \mathrm{~mm}$, height $\mathrm{x}$ diameter $\mathrm{x}$ wall width) with an upper lid and two apertures (Figure 1); ozone generator (Megazon); spectrophotometer (Hitachi); thermometer and hygrometer (CE); autoclave (Phoenix); microbiological oven (Fanen); microscope (PZO); incubator at $20-25^{\circ} \mathrm{C}$ (Dist.); microscope stereoscope (CarlZeiss Jena); colonies counter (Phoenix); analytical scale (Mettler); semi-analytical (CAB); homogenizer Ultra Turrax (IKA); industrial nut cracker (provided by CIEX, Manaus, AM, Brazil) and automatic pipettes $100 \& 1000 \mu 1$ with respective tips (Digipet) and. Liquid chromatograph (LC) system with $20 \mu$ loop injector (Rheodyne), isocratic pump, (M305, Gilson), fluorescence detector-FD (M121, Gilson) and reverse phase column $\mathrm{C}_{18}$ with $150 \mathrm{~mm}, 46 \mathrm{~mm}$ and $5 \mu \mathrm{m}$ for length, diameter and particle size, respectively (Phenomenex).

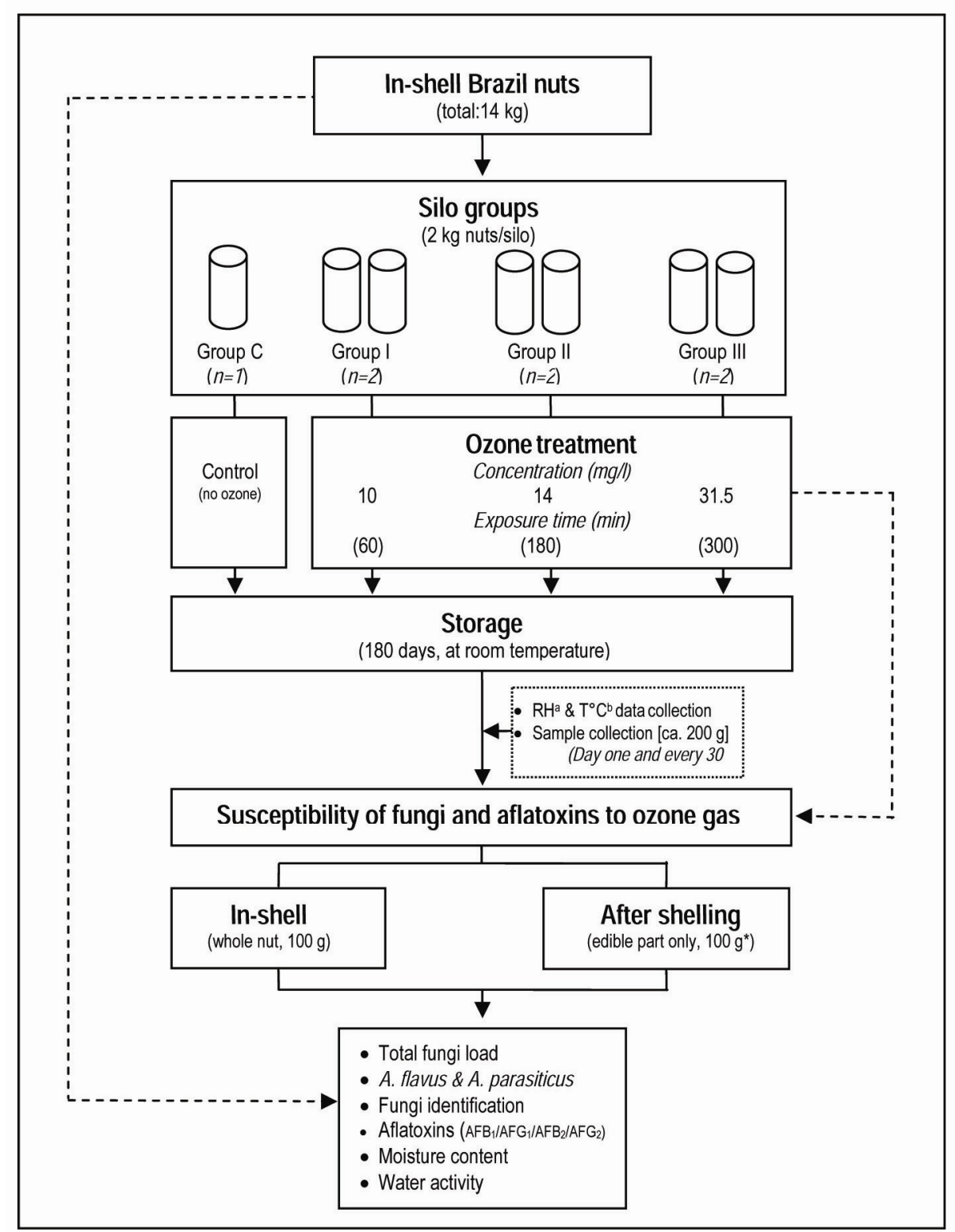

Figure 2. Chart flow of the in-shell Brazil nuts storage under $\mathrm{O}_{3}$ atmosphere study (*after shelling the weigth reduced to c.a. $80 \mathrm{~g}$ of edible part; ${ }^{a}$ relative humidity; ${ }^{\mathrm{b}}$ temperature)

\section{$2.4 \mathrm{O}_{3}$ Treatment and Storage}

The in-shell nuts, previously analysed for fungi load, mc, $\mathrm{a}_{w}$ and AFLs contamination, were aseptically weighted into portions of $2 \mathrm{~kg}$, divided into 4 Groups [C: as control (just air / no $\mathrm{O}_{3}$ application), I, II and III: for $\mathrm{O}_{3}$ treatment (concentrations of 10,14 and $31.5 \mathrm{mg} / \mathrm{l}$, respectively)], added into silos, upper lid closed and $\mathrm{O}_{3}$ treated. $O_{3}$ 
Treatment. Was carried out with $\mathrm{O}_{3}$ gas applied through the lower lateral silo aperture (Figure 1) by means of an $\mathrm{O}_{3}$ generator for one, 3 and 5 hours to reach the above $\mathrm{O}_{3}$ concentrations for nut Groups I, II and III, respectively $(n=2) . \mathrm{O}_{3}$ concentrations were checked by iodine metric analysis (McKenzie et al., 1997) by titration. Briefly, the gas was bubbled into a potassium iodide solution, acidified with sulfuric acid $1 \mathrm{~N}$ and solution titrated using sodium thiosulfate $0.005 \mathrm{~N}$ with starch solution as indicator (APHA, 1980). Storage. Silos top aperture were closed and nuts kept stored for 180 days. Sample Collection. Individual 200 g portions of Brazil nuts were aseptically collected from each silo, ground (whole-in-shell \& shelled, $100 \mathrm{~g}$ each), homogenized for the mycological tests, as well as for mc, $\mathrm{a}_{w}$ and AFLs analysis at Day One and every 30 days up to the end of storage period. Samples collected were in triplicate. Figure 2 shows the chart flow of whole study.

\subsection{Mycology Tests and AFLs Analysis}

Mycology. For total fungi count the method used was of Pit and Hocking (1997) by applying serial dilutions (10-1 to $10^{-4}$ ) on to the surface of MEA media. For fungi toxigenicity (AFLs) the method was of Machida and Saito (1999). The identification of fungi in genus and species was carried out according to the keys of Samsom (2004). The strains aflatoxigenicity was checked utilizing the AFPA by Pitt et al. (1983). AFLs Analysis. By LC/FD at 330 and $460 \mathrm{~nm}$ (extinction and emission, respectively). Mobile phase water:methanol:acetonitrile (60:15:15) (Sobolev et al., 2007). Method LOQ: 0.50/0.17/0.50/0.17 $\mu \mathrm{g} / \mathrm{kg}$ for $\mathrm{AFB}_{1} / \mathrm{AFB}_{2} / \mathrm{AFG}_{1} / \mathrm{AFG}_{2}$ and $1.34 \mu \mathrm{g} / \mathrm{kg}$ for total AFL.

\subsection{Nuts Mc \& Aw Determinations and Silos External Conditions}

$M c \& A w$. They were carried out by gravimetric (AOAC, 2005) and Aqua lab apparatus at $25^{\circ}$, respectively. $R H \&$ $T^{\circ} \mathrm{C}$. By daily measurements on site and also data obtained from the Santa Catarina Agriculture Research Company - EPAGRI/SC.

\subsection{Statistical Analysis}

They were performed by variance analysis (ANOVA) and included the Turkey's test to evaluate significant differences among the means $(\mathrm{p}<0.05)$ by GraphPad Prism 4.0 sofware. The results were expressed as the mean values and standard errors.

\section{Results and Discussion}

The total fungi load and aflatoxigenic species of Aspergillus, AFLs and mc variation during the storage of in-shell Brazil nuts under $\mathrm{O}_{3}$ atmosphere at different concentrations are shown in Tables 1 and 2. From the data obtained, it was possible to observe a direct correlation regarding the gas treatment effect on the fungi load and AFLs degradation, however that was dependent upon the $\mathrm{O}_{3}$ concentration used and time of storage. This is the first work carried out on in-shell Brazil nut $\mathrm{O}_{3}$ gas treated aiming to improve safety and quality regarding fungi and AFLs during storage.

\section{$3.1 \mathrm{O}_{3}$ Treatment Concentrations and Storage Time versus In-shell Brazil Nut Mycoflora}

(a) Total Fungi Load. As expected, the in-shell Brazil nuts ozonation showed to be effective for fungi/spores destruction during the period of storage. A reduction of total fungi count was registered since the first day after $\mathrm{O}_{3}$ application in all treated nut groups. However, the complete destruction of fungi (no grow: ng) was reached at different stages of storage depending upon the gas concentration applied. While fungi destruction occurred at the first day of $\mathrm{O}_{3}$ application when highest concentration was applied (Group III - $31.5 \mathrm{mg} / \mathrm{l}$ ), only after 30 days of storage, the same occurred for the 14.0 and $10 \mathrm{mg} / \mathrm{l}$ concentrations and kept up to the end of the storage. From the initial (untreated nuts) total fungi load of $4.83 \log \mathrm{cfu}$, it went (at Day One of the $\mathrm{O}_{3}$ treated nuts) down to 3.5,3.3 and nil log cfu/g for Groups I, II and III, respectively. Data quite different from those nuts of Control Group, which kept fungi load somewhat stable with a slight increase throughout the whole period of storage (from Day Zero/One to Day 180: 4.83 to $4.91 \mathrm{log} \mathrm{cfu} / \mathrm{g}$, respectively). Similar happened to those nuts when analyzed after being shelled (which were also used for sensory evaluation), however, in lower levels which was expected, as the edible part was shell protected, reducing possible fungi penetration, unless cracked.

From studies carried out on ozonation effect in nuts and other food, their reported data corroborate our findings, however applying lower $\mathrm{O}_{3}$ concentrations. In the current work it was utilized higher $\mathrm{O}_{3}$ concentrations due to the fact that the aim was more than just fungi disinfection. It was to evaluate AFLs degradation too and for that purpose the $\mathrm{O}_{3}$ concentration should be higher to reach the inner layers of the thick \& hard nut shell and so the nuts edible part. For that purpose it was necessary a higher concentration thus longer gas exposure, either to be effective and to reach and involve the most of the nuts (infected/contaminated) areas possible. Zhao and Cranston (1995) studied the effect of $\mathrm{O}_{3}$ on black peppers (which have higher contact surface and shells are thinner) at a lower gas concentration $(6.7 \mathrm{mg} / \mathrm{l})$ than in our study and reported fungi load reduction from 7 to 4 
$\log \mathrm{cfu} / \mathrm{g}$. In another study carried out in dried figs (which have thinner peel on) by Oztekin et al. (2006), $\mathrm{O}_{3}$ reduced the total fungi load from initial 1.46 to $0.40 \mathrm{log} \mathrm{cfu} / \mathrm{g}$ at $10 \mathrm{mg} / \mathrm{l}$. A work carried out in Brazil nut, however treating the nuts with aqueous $\mathrm{O}_{3}$ solutions $(0,1,10$ and $20 \mathrm{mg} / \mathrm{l})$ authors showed that they were effective to fungi control reaching an inactivation rate of $96 \%$ for $A$. flavus (Freitas et al, 2010), however that can lead to an increase of moisture, reducing crunchness and firmness characteristics, apart from other sensory characteristics alterations.

Table 1. Effect of ozone treatment on in-shell brazil nut mycoflor level and moisture content during storage

\begin{tabular}{|c|c|c|c|c|c|c|c|c|}
\hline \multicolumn{3}{|c|}{ Storage } & \multicolumn{6}{|c|}{ Brazil nut $^{\mathrm{a}}$} \\
\hline \multirow{3}{*}{ Days } & \multirow{2}{*}{\multicolumn{2}{|c|}{$\mathrm{O}_{3}$ treatment $^{\mathrm{b}}$}} & \multicolumn{4}{|c|}{ Fungi } & \multicolumn{2}{|c|}{$\mathrm{Mc}^{\mathrm{c} \pm \mathrm{SD}} / \operatorname{loss}(\%)$} \\
\hline & & & \multicolumn{2}{|c|}{ Total count (log cfu/g) } & \multicolumn{2}{|c|}{ Aspergillus aflatoxigenic species } & \multirow{2}{*}{ In-shell } & \multirow{2}{*}{ After shelling } \\
\hline & Nuts group & Conc. (mg/l) & In-shell & After shelling & In-shell & After shelling & & \\
\hline \multirow[t]{4}{*}{1} & $\mathrm{C}$ & $\mathrm{Nt}^{\mathrm{d}}$ & 4.83 & 2.54 & $\begin{array}{l}\text { A. flavus, } \\
\text { A. parasiticus }\end{array}$ & $\mathrm{Ng}^{\mathrm{e}}$ & $9.43\left(\mathrm{NA}^{\mathrm{f}}\right) \pm 0.10$ & $5.14(\mathrm{NA}) \pm 0.13$ \\
\hline & I & 10 & 3.5 & ng & $\begin{array}{l}\text { A. flavus, } \\
\text { A. parasiticus }\end{array}$ & ng & $7.72(6.61) \pm 0.01$ & $3.97(6.25) \pm 0.03$ \\
\hline & II & 14 & 3.3 & ng & $\begin{array}{l}\text { A. flavus, } \\
\text { A. parasiticus }\end{array}$ & ng & $7.71(7.58) \pm 0.02$ & $3.96(6.89) \pm 0.01$ \\
\hline & III & 31.5 & ng & ng & ng & ng & $7.68(8.56) \pm 0.04$ & $3.95(7.52) \pm 0.01$ \\
\hline \multirow[t]{4}{*}{30} & $\mathrm{C}$ & $\mathrm{nt}$ & 4.84 & 2.57 & $\begin{array}{l}\text { A. flavus, } \\
\text { A. parasiticus }\end{array}$ & ng & 9.57 (NA) \pm 0.08 & $5.28(\mathrm{NA}) \pm 0.09$ \\
\hline & I & 10 & $\mathrm{ng}$ & ng & ng & ng & $7.67(10.22) \pm 0.06$ & $3.95(8.04) \pm 0.07$ \\
\hline & II & 14 & $\mathrm{ng}$ & ng & ng & ng & $7.66(10.60) \pm 0.03$ & $3.94(8.67) \pm 0.01$ \\
\hline & III & 31.5 & $\mathrm{ng}$ & ng & ng & ng & $7.64(11.74) \pm 0.02$ & $3.93(9.29) \pm 0.06$ \\
\hline \multirow[t]{4}{*}{60} & $\mathrm{C}$ & $\mathrm{nt}$ & 4.86 & 2.60 & $\begin{array}{l}\text { A. flavus, } \\
\text { A. parasiticus }\end{array}$ & ng & $9.63(\mathrm{NA}) \pm 0.09$ & $5.32(\mathrm{NA}) \pm 0.14$ \\
\hline & I & 10 & ng & ng & ng & ng & $7.63(11.65) \pm 0.06$ & $3.93(9.03) \pm 0.01$ \\
\hline & II & 14 & ng & ng & ng & $\mathrm{ng}$ & $7.61(12.59) \pm 0.03$ & $3.90(9.65) \pm 0.05$ \\
\hline & III & 31.5 & $\mathrm{ng}$ & $\mathrm{ng}$ & ng & $\mathrm{ng}$ & $7.58(13.34) \pm 0.03$ & $3.88(10.28) \pm 0.06$ \\
\hline \multirow[t]{4}{*}{90} & $\mathrm{C}$ & $\mathrm{nt}$ & 4.88 & 2.62 & $\begin{array}{l}\text { A. flavus, } \\
\text { A. parasiticus }\end{array}$ & ng & $9.84(\mathrm{NA}) \pm 0.10$ & $5.46(\mathrm{NA}) \pm 0.13$ \\
\hline & I & 10 & ng & ng & ng & ng & $7.56(14.65) \pm 0.07$ & $3.87(11.38) \pm 0.03$ \\
\hline & II & 14 & ng & ng & ng & ng & $7.54(15.75) \pm 0.05$ & $3.87(12.29) \pm 0.04$ \\
\hline & III & 31.5 & ng & ng & ng & ng & $7.51(16.11) \pm 0.04$ & $3.60(12.50) \pm 0.06$ \\
\hline \multirow[t]{4}{*}{120} & $\mathrm{C}$ & $\mathrm{nt}$ & 4.89 & 2.65 & $\begin{array}{l}\text { A. flavus, } \\
\text { A. parasiticus }\end{array}$ & ng & 9.89 (NA) \pm 0.10 & $5.51(\mathrm{NA}) \pm 0.15$ \\
\hline & I & 10 & $\mathrm{ng}$ & ng & ng & ng & $7.47(16.15) \pm 0.05$ & $3.85(12.23) \pm 0.09$ \\
\hline & II & 14 & ng & ng & ng & ng & $7.43(17.78) \pm 0.03$ & $3.84(13.14) \pm 0.08$ \\
\hline & III & 31.5 & ng & ng & $\mathrm{ng}$ & ng & $7.41(17.96) \pm 0.07$ & $3.82(13.34) \pm 0.01$ \\
\hline \multirow[t]{4}{*}{180} & $\mathrm{C}$ & $\mathrm{nt}$ & 4.91 & 2.69 & $\begin{array}{l}\text { A. flavus, } \\
\text { A. parasiticus }\end{array}$ & ng & $9.93(\mathrm{NA}) \pm 0.08$ & $5.63(\mathrm{NA}) \pm 0.07$ \\
\hline & I & 10 & ng & ng & ng & ng & $7.37(18.82) \pm 0.07$ & $3.80(12.99) \pm 0.03$ \\
\hline & II & 14 & ng & ng & ng & ng & $7.35(19.89) \pm 0.04$ & $3.78(13.79) \pm 0.01$ \\
\hline & III & 31.5 & ng & ng & $\mathrm{ng}$ & $\mathrm{ng}$ & $7.32(19.89) \pm 0.02$ & $3.76(14.19) \pm 0.05$ \\
\hline
\end{tabular}

${ }^{\mathrm{a}}$ nuts were evaluated for fungi whole (in-shell + edible part) and after shelling (only edible part); ${ }^{\mathrm{b}}$ nuts Groups: C $=$ control (no $\mathrm{O}_{3}$ treatment), I, II $\left(\mathrm{O}_{3}\right.$ conc. $\left.=14 \mathrm{mg} / \mathrm{L}\right)$ and $\mathrm{III}\left(\mathrm{O}_{3}\right.$ conc. $\left.=31.5 \mathrm{mg} / \mathrm{l}\right) ;{ }^{\mathrm{c}}$ moisture content (initial $\mathrm{mc}=9.43 \%$ \& total fungi load initial $\left.=6.9 \times 10^{4}\right) ;{ }^{\mathrm{d}}$ not treated; ${ }^{\mathrm{e}}$ no growth; ${ }^{\mathrm{f}}$ no applicable. Storage temperature: $20^{\circ} \mathrm{C}\left(16.6-20.6^{\circ} \mathrm{C}\right)$ and relative humidity: $80 \%(75.8-85.3 \%)$. Nuts initial and final water activity: 0.82 and 0.63 . More often fungi species isolated from untreated stored nuts (Control Group); Acremonium sp; A. ochraceus; Cladosporium sp.; P. corylophium and Rhizopus sp. followed by $A$ niger; A. parasiticus; A. versicolor and $P$. crustosum; isolated fungi toxigenic potential: Aspergillus (A. flavus; A. parasiticus) and Penicillium (P. citrinum) were able to produce AFLs and citrinin (CTR), respectively.

(b) Aflatoxigenic Species of Aspergillus. Regarding the isolation of aflatoxigenic species of Aspergillus (A. flavus and $A$. Parasiticus) in the Brazil nuts just after the $\mathrm{O}_{3}$ treatments, only the highest $\mathrm{O}_{3}$ concentration treated nuts 
(Group III - $31.5 \mathrm{mg} / \mathrm{l}$ ) did not allow them to growth since Day One after the gas application. The same occurred to the Groups of lower $\mathrm{O}_{3}$ concentrations, however after 30 days of storage (Table 1). As expected, the Control Group had those species being detected on the nuts throughout the whole storage period. Similar happened when Mason et al. (1997) applied $\mathrm{O}_{3}(5 \mathrm{mg} / \mathrm{l})$ in cultures of $A$. flavus Link and Fusarium verticilioides. It inhibited the growth and sporulation. Kells et al. (2001) studied the efficacy of $\mathrm{O}_{3}$ as a fumigant to disinfest stored maize (50 mg/l), apart from insects; it also reduced by $63 \%$ the contamination level of A. parasiticus on the kernels.

(c) Other Fungi: Apart from the A. flavus, and A. parasiticus that were isolated on AFPA media, other fungi genera and species were also isolated utilizing MEA media. The more often isolated species from the untreated nuts (Control) group during the storage were Acremonium sp; A. ochraceus; Cladosporium sp.; P. corylophium and Rhizopus sp. followed by A niger; A. parasiticus; A. versicolor and P. crustosum. Regarding the toxigenic potential of those fungi isolated, Aspergillus (A. flavus; A. parasiticus) and Penicillium citrinum were able to produce AFLs and also citrinin (CTR), respectively. The fact that other fungi strains and some toxigenic (CTR) were detected in the Control Group, was probably because the nuts were obtained in the retail market of Southern Brazil and not in the Amazon region, thus exposed to different fungi species spores through manipulation and/or different environments, from tropical to temperate climate, respectively. These fungi were found from the beginning until the end of storage (Table 1). They did not have an accentuated growth though, due to the mild $\left(80 \% \mathrm{RH} ; 20^{\circ} \mathrm{C}\right)$ environmental conditions of the storage in Southern Brazil (Figure 1), lower nut mc and silos being tightly closed (reaching hermetic conditions). Important to emphasize that after the $\mathrm{O}_{3}$ treatment, nuts from Groups I and II at Day One still presented the following fungi strains showing to be more gas resistant: A. flavus, A. parasiticus, P. penicilioides, Byssochlamys, Cladosporium P. corylophium, P crusdtosum, $P$. naugioviense, $P$ variable, Rhizopus sp, and $P$ viridicatum.

\section{$3.2 \mathrm{O}_{3}$ Treatment versus In-shell Brazil Nut AFL Contaminated}

Table 2. Effect of Ozone Treatment on In-shell Brazil nut Aflatoxins Level

\begin{tabular}{|c|c|c|c|c|c|c|c|}
\hline \multirow{3}{*}{ Days } & \multicolumn{2}{|l|}{ Storage } & \multicolumn{5}{|c|}{ Brazil nut $^{\mathrm{a}}$} \\
\hline & \multicolumn{2}{|c|}{$\mathrm{O}_{3}$ treatment $^{\mathrm{b}}$} & \multicolumn{5}{|c|}{$\begin{array}{c}\text { Aflatoxins (in-shell / after shelling) } \\
(\mu \mathrm{g} / \mathrm{kg})^{\mathrm{c}}\end{array}$} \\
\hline & Nuts group & Conc. $(\mathrm{mg} / \mathrm{l})$ & $\sum$ AFLs $^{\mathrm{d}}$ & $\mathrm{AFB}_{1}$ & $\mathbf{A F G}_{1}$ & $\mathbf{A F B}_{2}$ & $\mathbf{A F G}_{2}$ \\
\hline \multirow[t]{4}{*}{1} & $\mathrm{C}$ & $\mathrm{Nt}^{\mathrm{e}}$ & $11.58 / 6.61^{*}$ & $3.48 / 1.16$ & $3.57 / 1.89$ & $2.21 / 2.02$ & $2.32 / 1.74$ \\
\hline & I & 10 & $3.01 / \mathrm{ND}^{\mathrm{f}}$ & 3.01 & ND & ND & ND \\
\hline & II & 14 & ND & ND & ND & ND & ND \\
\hline & III & 31.5 & ND & ND & ND & ND & ND \\
\hline \multirow[t]{4}{*}{30} & $\mathrm{C}$ & nt & $12.06 / 8.01$ & $3.69 / 1.37$ & $3.78 / 2.73$ & $2.23 / 2.05$ & $2.36 / 1.86$ \\
\hline & I & 10 & ND & ND & ND & ND & ND \\
\hline & II & 14 & ND & ND & ND & ND & ND \\
\hline & III & 31.5 & ND & ND & ND & ND & ND \\
\hline \multirow[t]{4}{*}{60} & $\mathrm{C}$ & $\mathrm{nt}$ & $12.24 / 7.95$ & $3.83 / 1.16$ & $3.82 / 2.83$ & $2.22 / 2.08$ & $2.37 / 1.88$ \\
\hline & I & 10 & ND & ND & ND & ND & ND \\
\hline & II & 14 & ND & ND & ND & ND & ND \\
\hline & III & 31.5 & ND & ND & ND & ND & ND \\
\hline \multirow[t]{4}{*}{90} & $\mathrm{C}$ & $\mathrm{nt}$ & $12.34 / 8.03$ & $3.86 / 1.14$ & $3.86 / 2.86$ & $2.25 / 2.10$ & $2.37 / 1.93$ \\
\hline & I & 10 & ND & ND & ND & ND & ND \\
\hline & II & 14 & ND & ND & ND & ND & ND \\
\hline & III & 31.5 & ND & ND & ND & ND & ND \\
\hline \multirow[t]{4}{*}{120} & $\mathrm{C}$ & $\mathrm{nt}$ & $12.49 / 8.08$ & $3.94 / 1.14$ & $3.88 / 2.88$ & $2.27 / 2.11$ & $2.40 / 1.95$ \\
\hline & I & 10 & ND & ND & ND & ND & ND \\
\hline & II & 14 & ND & ND & ND & ND & ND \\
\hline & III & 31.5 & ND & ND & ND & ND & ND \\
\hline \multirow[t]{4}{*}{180} & $\mathrm{C}$ & $\mathrm{nt}$ & $12.55 / 8.17^{*}$ & $3.95 / 1.13$ & $3.90 / 2.91$ & $2.28 / 2.17$ & $2.42 / 1.96$ \\
\hline & I & 10 & ND & ND & ND & ND & ND \\
\hline & II & 14 & ND & ND & ND & ND & ND \\
\hline & III & 31.5 & ND & ND & ND & ND & ND \\
\hline
\end{tabular}

${ }^{a}$ nuts were evaluated for fungi whole (in-shell + edible part) and after shelling (only edible part); ${ }^{b}$ nuts Groups: $\mathrm{C}=$ control (no $\mathrm{O}_{3}$ treatment), I, II $\left(\mathrm{O}_{3}\right.$ conc. $\left.=14 \mathrm{mg} / \mathrm{L}\right)$ and III $\left(\mathrm{O}_{3}\right.$ conc. $\left.=31.5 \mathrm{mg} / \mathrm{l}\right) ;{ }^{c} \mathrm{AFLs} \mathrm{level,} \mathrm{duplicate;}$ Method limit of detection: $0.50 ; 0.17 ; 0.50$ and $0.17 \mu \mathrm{g} / \mathrm{kg}$ for $\mathrm{AFB}_{1}, \mathrm{AFB}_{2}, \mathrm{AFG}_{1}$ and $\mathrm{AFG}_{2}$, respectively; ${ }^{\mathrm{d}} \mathrm{AFB}_{1}+\mathrm{AFG}_{1}+\mathrm{AFB}_{2}+\mathrm{AFG}_{2} ;{ }^{\mathrm{e}}$ not treated; ${ }^{\mathrm{f}}$ not detected. $*<0.05$ 
In contrary to the nuts Control Group, a reduction on the AFL levels was detected throughout the whole storage period of the in-shell Brazil nuts $\mathrm{O}_{3}$ treated (Table 2). In fact, just after the $\mathrm{O}_{3}$ treatments, either at gas concentrations of 14 or $31.5 \mathrm{mg} / \mathrm{l}$, the Brazil nuts did not present AFLs contamination - up to the method LOQ $\left(0.50 / 0.17 / 0.50 / 0.17 \mu \mathrm{g} / \mathrm{kg}\right.$ for $\mathrm{AFB}_{1} / \mathrm{AFB}_{2} / \mathrm{AFG}_{1} / \mathrm{AFG}_{2}$, respectively). Although the three concentrations applied were able to degrade the toxins, some AFLs were still detected i.e., $3.01 \mu \mathrm{g} / \mathrm{kg}$ ( $74 \%$ reduction) at the lower $\mathrm{O}_{3}$ concentration $(10 \mathrm{mg} / \mathrm{l})$. The toxins were able to be totally degraded after 30 days though. Important to emphasize that the Control Group slightly increased and/or kept the nuts AFL level from the beginning to the end of storage period ( 11.58 to $12.55 \mu \mathrm{g} / \mathrm{kg}$, respectively) indicating no significant changes $(<0.05)$. That can be explained by the controlled experiment environment and storage conditions applied (low $\mathrm{T}^{\circ} \mathrm{C}, \mathrm{RH}, \mathrm{mc} \& \mathrm{a}_{w}$ ). Although studies on $\mathrm{O}_{3}$ effect have been published on fungi in different foods, only a few are on AFLs degradation (Dollear et al., 1968, Yesilcimen et al., 2006,) and their findings corroborate to our experiment data, with reduction from 75 to $100 \%$, depending on the gas concentration/time of exposure, type and characteristics of food utilized.

\section{$3.3 \mathrm{O}_{3}$ Treatment Effect on In-shell Brazil Nuts $M c \& A_{w}$ and Storage Environmental Conditions}

$M c \& A_{w}$. During the nuts storage of the 3 silos $\mathrm{O}_{3}$ groups, nuts reduced their mc from initial $9.4 \%$ i.e., prior $\mathrm{O}_{3}$ treatments, to ca. $7 \%$ corresponding to $22 \%$ of total $\mathrm{mc}$ loss at the end the of storage period. The mc reduction per nut group during storage was: from $9.4 \%$ (untreated- Control Group) at Day Zero to 7.4 (reduction of 21.8\%), $7.4(22.1)$ and $7.32(22.3) \%$ for $\mathrm{O}_{3}$ treated nuts Groups I, II and III, respectively at the end of storage (Table 1). That reduction may have occurred due to the $\mathrm{O}_{3}$ gas stream nut exposure time utilized to reach the target concentrations (1, 3, 5 hours) or due to the environment low RH. The loss of moisture can lead to an unfavorable environment for fungi growth. Regarding $\mathrm{a}^{w}$ levels, similar situation occurred, reduced from 0.82 to 0.63 from the initial to final storage time, respectively corroborating the safety of the condions applied. According to Pacheco and Scussel (2007), mc can still be considered safe up to $8 \%$, fungi growth wise. On the other hand, Codex Alimentarius recommends mc of $13 \pm 4 \%$ and $\mathrm{a}_{w}$ of 0.7 (CAC, 2006).

Storage Environment Conditions. The rain precipitation, as well as other environmental conditions such as temperature and RH data (Figure 3) that are considered factors to influence fungal growth and AFL formation were monitored in and outdoors during the storage period. Rain precipitation: the experiment started in May, and up to June the rain precipitation was of $80 \mathrm{~mm}$ (month average), it went down to $10 \mathrm{~mm}$ in July and then increased again, reaching $300 \mathrm{~mm}$ in October average of $126(\min 10$; $\max 300) \mathrm{mm}$. $R H$ : throughout the storage period RH was somewhat low with 80 (75.8 to 85.5)\%. Temperature: the temperature average was 20 (min.16.6, max. 20.6) ${ }^{\circ} \mathrm{C}$ which was not optimal for fungi proliferation either. That is one of the reasons for the Control Group fungi contamination to remain similar (4.83 to $4.91 \mathrm{logcfu} / \mathrm{g}$ ) during the whole experiment.

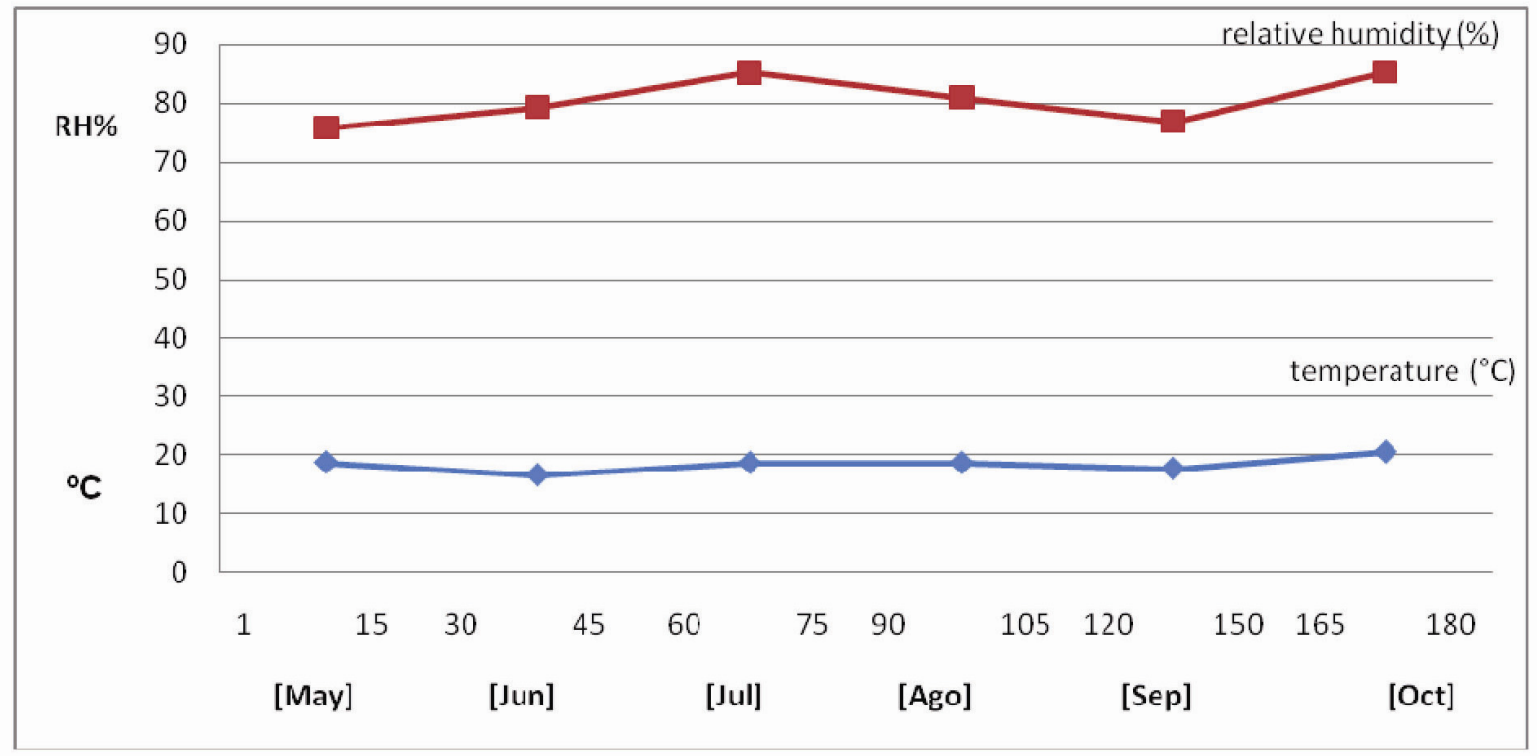

Figure 3. Relative humidity and temperature (averages/month) during the storage of in-shell Brazil nut $\mathrm{O}_{3}$ treated experiments (May to October -2008) 
Those conditions in the present experiment, together with other factors related (silos tightly closed, low mc) reduced the possibility of fungi growth and AFLs formation, as well as rancidity development, when compared to optimal conditions of $30^{\circ} \mathrm{C}, 80-85 \%$ RH (Pacheco et al., 2006) and $\mathrm{mc}>8 \%$ (Pacheco et al., 2007b). The environmental conditions are very important, since the collection of Brazil nuts in the forest up to the reach of the stores for sale. In a work carried out by Pacheco and Scussel (2009) the authors reported that during the Brazil nut colletion in the Amazon forest from April to May, had much higher rain precipitation index with means of 496.2 and $440.3 \mathrm{~mm}$, in 2006 and 2007, respectively. For the RH outdoors of the factory, the authors reported varying from 80 to $96 \%$ for April and 80 to $93 \%$ for May in 2006, with average of $85.6 \%$ for both months; which were quite different to the storage conditions present in the current retail market nuts study.

Regarding the effect of the $\mathrm{O}_{3}$ concentration and time of storage on the in-shell Brazil nuts lipid stability and their sensory attributes quality achieved, that gas was not able to deeply influence the lipid oxidation and the sensory attributes of nut quality under the experiment conditions despite of the $\mathrm{O}_{3}$ concentration used. In contrary, due to the gas stream exposure, apart from keeping nuts cruncher, reduce any off odor resulting a more acceptable batch, buyer/consumer wise. Those data were detailed investigated and reported by the same research Group (Giordano et al., 2012).

\section{Conclusion}

$\mathrm{O}_{3}$ treatment can be an effective method for reduction/control of nut deterioration and toxin decontamination in the market. Regarding the more effective $\mathrm{O}_{3}$ concentration, by utilizing the $31.5 \mathrm{mg} / \mathrm{l}$, nuts can get fungi destroyed and AFLs since the first day of application, under the conditions applied in the current experiment.

Data showed that $\mathrm{O}_{3}$ treatment prior storage can prolong the in-shell Brazil nuts self-life and could be applied on nuts for export prior shipping (in containers) held in bags, also in-land in storage silos. Currently, in-shell Brazil nuts are shipped either in bulk (loose) or in big-bags. By applying $\mathrm{O}_{3}$ in the container specially built for that purpose, nuts could be kept away from fungi and last safer longer. Also, fungi reduction just after harvesting in the forest by applying $\mathrm{O}_{3}$ in storage silos will certainly reduce the possibility of further mycelia proliferation and possible AFL formation.

$\mathrm{O}_{3}$ could be applied in other stages of the Brazil nuts productive chain (prior transporting, processing and during packaging (Scussel et al., 2011) in the country.

From a food quality and safety point of view prevention is a better strategy than detoxification. However, when contamination is eminent and can not be avoided, a practical method as $\mathrm{O}_{3}$ could be an alternative. Despite of the findings, there is a need of more studies, especially on application (a) in pilot plants, (b) larger amounts of nut, (c) under the Amazon forest environment (first and second storages) and/or prior factory processing, in order to establish the optimal applicable $\mathrm{O}_{3}$ gas concentration and time of exposure for maximum effectiveness utilizing the present findings.

Important to emphasize that gaseous $\mathrm{O}_{3}$ decomposes to form $\mathrm{O}_{2}$ and it does not affect the environment, nor leave residues in the nuts, apart from low cost technology and simple technique to apply. Despite this, $\mathrm{O}_{3}$ can be toxic if inhaled in large amount which shows that it must be handled with care. This work is part of a Research Project on "Technology Development for Prevention and Control of AFLs in Stored Brazil Nuts" that has been developed in the Food and Technology Department of the Federal University of Santa Catarina/SC, Brazil.

\section{Acknowledgment}

Authors thank de Mello, F. R. for providing the Brazil nut samples and Simao, V. for carried out the LC AFLs analysis.

\section{References}

Allen, B., Wu, J., \& Doan, H. (2003). Inactivation of fungi associated with barley grain by ozone. J. Environ. Sci. Health B., 38 (5), 617-630. http://dx.doi.org/10.1081/PFC-120023519

APHA - American Public Health Association. (1980). Standard methods for the examination of water and was and wastewater. (15 ed.) Washington: American Public Health Association.

Arrus, K., Blank, G., Abramson, D., Clear, R., \& Holley, R. A. (2005). AFL production by Aspergillus flavus in Brazil nuts. J. Stored Prod. Res., 41, 513-527.

CAC- Codex Alimentarius Commission. (2005). Codex on Food Additives and Contaminants Committee, Code of practice for the prevention and reduction of aflatoxin contamination in tree nuts, CAC/RCP 59. 
CAC- Codex Alimentarius Commission. (2006). Code of practice for the prevention and reduction of aflatoxin contamination in tree nuts. CAC/RCP 59-2005, Rev. 1-2006.

De-Mello, F. R., \& Scussel, V. M. (2007). Characteristics of in-shell Brazil nuts and their relationship to aflatoxin contamination: criteria for sorting. J. Agric. Food Chem., 55, 9305-9310. http://dx.doi.org/10.1021/jf071392x

Dollear, F. G., Mann, G. E., Codifer Jr.,. L. P., Gardner Jr., H. K., Koltun, S. P., \& Vix, H. L. E. (1968). Elimination of aflatoxin from peanut meal. J. Am. Oil Chem.Soc., 45, 862-865. http://dx.doi.org/10.1007/BF02540171

Dwarakanath, C. T., Rayner, E. T., Mann, G. E., \& Dollear, F. G. (1968). Reduction of aflatoxin levels in cottonseed and peanut meals by ozonization. J. Am. Oil Chem. Soc., 45, 93-95.

Farag, R. S., Rashed, M. M., \& Abo-Hgger, A. A. A. (1996). Aflatoxin destruction by microwave heating. Int. J. Food Sci. Nutr., 47, 197-208. http://dx.doi.org/10.3109/09637489609012581

Freire, F. das C. O., Kozakiewicz, Z., \& Paterson, R. R. M. (2000). Mycoflora and mycotoxins in Brazilian black pepper, white pepper and Brazil nuts. Mycopathologia, 149, 13-19.

Freitas, O., de Souza, M. W., \& Venancio, A. (2010). In: VI Latin American Mycotoxicology Congress, June, Merida, Mexico. Book of Abstracts.

Giordano, B. E. N., Savi, G., \& Scussel, V. M. (2012). Ozone gas effect on in-shell Brazil nuts lipid stability and sensory characteristics during storage treatment. Current Nutr. Food Sci. In press.

Hwang, E., Cash, J. N., \& Zabik, M. J. (2001). Postharvest treatments for the reduction of Mancozeb in fresh apples. J. Agric. Food Chem., 49, 3127-3132. http://dx.doi.org/10.1021/jf010234h

Kells, A. A., Mason, L. J., Maier, D. E., \& Wolushuk, C. P. (2001). Efficacy and fumigation characteristics of ozone in stored maize. J. Stored Prod. Res., 37, 371-382. http://dx.doi.org/10.1016/S0022-474X(00)00040-0

Kurtzman, C. P., Horn, B. W., \& Hesseltine, C. W. (1987). Aspergillus nomius, a new aflatoxin producing species related to $A$. flavus and A. tamarii. Antonie van Leeuwenhoek, 53, 147-158. http://dx.doi.org/10.1007/BF00393843

Lanita, C. S., \& da Silva, S. B. (2008), Use of ozone in industrial cold rooms to control yeasts and moulds during parmesan cheese ripening. Braz. J. Food Technol., 11(3), 182-189.

Machida, S., \& Saito, M. (1999). A rapid identification method for aflatoxin-producing strains of Aspergillus flavus and A. parasiticus by ammonia vapor. Mycoscience, 40, 205-208.

Mason, L. J., Woloshuk, C. P., \& Maier, D. E. (1997). Efficacy of ozone to control insects, molds and mycotoxins. In Donahaye, E.J., Navarro, S., Varnava, A. Editors, Proceedings of the International Conference on Controlled Atmosphere and Fumigation in Stored Products, Nicosia, Cyprus Printer Ltd., Nicosia, 665-670.

Olmez, H., \& Akbas, M. Y. (2009). Optimization of ozone treatment of fresh-cut green leaf lettuce. J. Food Eng., 90, 489-494. http://dx.doi.org/10.1016/j.jfoodeng.2008.07.026

Olsen, M., Johsson, P., Moller, T., Paladino, R., \& Lindblat, M. (2008). Aspergillus nomius, an important aflatoxin producer in Brazil nuts? World Mycotoxin J., l(2), 123-126. http://dx.doi.org/10.3920/WJ2008.1032

Oztekin, S., Zorlugenç, B., \& Zorlugenç, F. K. (2006). Effects of ozone treatment on microflora of dried figs. J. Food Eng., 75, 396-399. http://dx.doi.org/10.1016/j.jfoodeng.2005.04.024

Pacheco, A. M., \& Scussel, V. M. (2009). Aflatoxins evaluation on in-shell and shelled dry Brazil nuts for export analysed by LC-MS/MS-2006 and 2007 harvests. Wold Mycotoxin J., 2, 295-304. http://dx.doi.org/10.3920/WJ2008.1077

Pacheco, A. M., \& Scussel, V. M. (2006). Castanha do Brasil - from the Forest to Consumer. Ed. Editograff, Brazil, $174 \mathrm{pp}$.

Pacheco, A. M., \& Scussel, V. M. (2007). Selenium and aflatoxin levels in raw Brazil nuts from the Amazon basin. J. Agric. Food Chem., 55, 11087-11092. http://dx.doi.org/10.1021/jf072434k

Perez, A. G., Sanz, C., Rios, J. J., Olias, R., \& Olias, J. M. (1999). Effects of ozone treatment on postharvest strawberry quality. J. Agric. Food Chem., 47, 1652-1656. http://dx.doi.org/10.1021/jf9808291 
Pitt, J. I., \& Hocking, A. D. (1997). Fungi and Food Spoilage. 2ed. London: Blackie Academic \& Profissional, $593 \mathrm{p}$.

Pitt, J. I., Hocking, A. D., \& Glenn, D. R. (1983). An improved medium for the detection of Aspergillus flavus and A.parasiticus. J. Appl. Bacteriol., 54, 109-114. AOAC - Official Methods of Analysis of AOAC International (2005). Nuts and Nuts Prod. art. 925.40, $18^{\text {th }}$ ed. Vol II, chapter 40.

Proctor, A. D., Ahmedna, M., Kumar, J. V., \& Goktepe, I. (2004). Degradation of aflatoxins in peanut kernels/flour by gaseous ozonation and mild heat treatment. Food Add. and Cont., 21, 786-793. http://dx.doi.org/10.1080/02652030410001713898

Samsom, R. A., Hoesktra, E. S., \& Frisvad, J. C. (2004). Introduction to Food and Airborne Fungi. $7^{\text {th }}$ edition, CBS. The Netherlands, 389p.

Scussel, V. M., Giordano, B. N. E., Simao, V., Manfio, D., Galvao, S., \& Rodrigues, M. de N. F. (2011). Effect of oxygen-reducing atmospheres on the safety of packaged shelled Brazil nuts during storage. International J. Analytical Chemistry, 1-9. http://dx.doi.org/10.1155/2011/813591

Sharma, R. R., Demirci, A., Beuchat, L. R., \& Fett, W. F. (2002). Inactivation of Escherichia coli O157:H7 on inoculated alfalfa seeds with ozonated water and heat Treatment. J. Food Prot., 65(3), 447-451.

Simsek, O., Arici, M., \& Demir, C. (2002). Mycoflora of hazelnut (Corylus avellana L.) and aflatoxin content in hazelnut kernels artificially infected with Aspergillus parasiticus. Nahrung, 46, $194-196$. http://dx.doi.org/10.1002/1521-3803(20020501)46:3<194::AID-FOOD194>3.0.CO;2-D

Sobolev, V. S. (2007). Simple, rapid, and inexpensive cleanup method for quantitation of aflatoxins in important agricultural products by HPLC. J. Agric. Food Chem., 55, 2136-2141. http://dx.doi.org/10.1021/jf063669j

Yesilcimen, A. M., \& Murat, O. (2006). Effect of different treatments on aflatoxin degradation and physicochemical properties of pistachios. J. Sci. Food Agric., 86(13), 2099-2104.

Zhao, J., \& Cranston, P. M. (1995). Microbial descontamination of black pepper by ozone and the effects of the treatment on volatile oil constitutes of the spices. J. Sci. Food Agric., 68, 11-18. http://dx.doi.org/10.1002/jsfa.2740680103 